\title{
Efficacy of Strontium Ranelate in Combination with a D-Hormone Analog for the Treatment of Postmenopausal Osteoporosis
}

\author{
Lola S. Abboskhujaeva • Saydiganikhodja I. Ismailov • \\ Nodira M. Alikhanova
}

Published online: 6 December 2014

(c) The Author(s) 2014. This article is published with open access at Springerlink.com

\begin{abstract}
Background Vitamin D supplements are recommended in individuals with vitamin D insufficiency and established osteoporosis to reduce risk of fracture and falling. Active vitamin D metabolites have been found to be more effective for fall prevention than native vitamin D.

Objectives The aim of this study was to compare the efficacy of strontium ranelate in combination with alfacalcidol and strontium ranelate alone on bone mineral density (BMD) and fall risk in postmenopausal women with osteoporosis.

Methods A total of 48 women (mean age 62.4 years) with postmenopausal osteoporosis were randomized to strontium ranelate monotherapy $2 \mathrm{~g} /$ day $(n=16)$, strontium ranelate $2 \mathrm{~g}$ /day plus alfacalcidol $1 \mu \mathrm{g}(n=16)$ or control $(n=16)$ and followed for 6 months. All women received calcium and vitamin $\mathrm{D}_{3}$ supplements. BMD was measured at the lumbar spine and proximal femora at the beginning and end of therapy. Patients performed functional tests such as the "up and go" and chair rising tests to estimate risk of fall status. Biochemical markers of bone turnover were also assessed.

Results Statistically significant increases in BMD compared with baseline values and the control group were observed in both strontium ranelate treatment groups. Increases were also statistically significant in the strontium ranelate combination group compared with strontium
\end{abstract}

L. S. Abboskhujaeva · S. I. Ismailov $(\square) \cdot$ N. M. Alikhanova Center for the Scientific and Clinical Study of Endocrinology, 56 Mirzo-Ulugbek str., 100125 Tashkent, Uzbekistan e-mail: ismailov.said@list.ru

L. S. Abboskhujaeva - S. I. Ismailov - N. M. Alikhanova Public Health Ministry, Tashkent, Uzbekistan ranelate alone. Strontium ranelate combination therapy for 6 months improved patients' ability to perform functional tests as well as increasing the number of women capable of performing the tests. No significant changes were observed in women receiving strontium ranelate monotherapy or in the control group. Serum levels of $\beta$-CrossLaps, a marker of bone resorption, were significantly reduced compared with control in both strontium ranelate groups. A significantly greater reduction was observed in the strontium ranelate combination group compared with strontium ranelate alone $(24.0 \% ; P=0.008)$. Increases in type 1 procollagen total $\mathrm{N}$-terminal propeptide (TP1NP), a marker of bone formation, reached statistical significance in both strontium ranelate groups compared with baseline.

Conclusion Strontium ranelate and alfacalcidol combination therapy improves bone quality, fall risk and markers of bone turnover to a greater extent than strontium ranelate alone in patients with established osteoporosis.

\section{Introduction}

Osteoporosis is prevalent worldwide, and as one of the major causes of increased morbidity and mortality in postmenopausal women and the overall aging population, it is considered a serious public health concern. Epidemiological studies conducted in the Russian Federation report prevalences in women and men aged 50 years or older of $30.5-33.1$ and $22.8-24.1 \%$, respectively [1]. Based on the current population size, it is estimated that one in three women and one in five men in this age group have osteoporosis, which thus affects more than 10 million people [1]. Similar rates of osteoporosis are reported in Caucasian populations in North America and some countries in Western Europe [2-4]. The incidence of osteopenia and 
osteoporosis among perimenopausal female residents of Tashkent, the capital of the Republic of Uzbekistan, is 55.7 and $12.2 \%$, respectively [5].

Although a reduced bone mineral density (BMD) is a major risk factor for all osteoporotic fractures, risk of a fall is considered even more significant among risk factors for nonvertebral fractures [6-9]. While many causes may underlie the risk of a fall, the inability of an individual to adequately respond to loss of balance as well as center-ofgravity shifts are key factors. In this respect, the importance of vitamin D is well established. The term vitamin D collectively refers to a group of structurally similar chemicals and their metabolites, which include cholecalciferol (vitamin $\mathrm{D}_{3}$ ), calcitriol (1,25-dihydroxycholecalciferol), alfacalcidol (alfa $\mathrm{D}_{3}$ ) (1-hydroxycholecalciferol), and ergocalciferol (vitamin $\mathrm{D}_{2}$ ). D-hormone analogs such as alfa $\mathrm{D}_{3}$ have been shown to produce positive effects on the processes of bone tissue remodeling and bone microarchitecture [10]. D-hormone analogs also have positive effects on skeletal muscles, orthostatic tolerance and fall risk reduction. Receptors are present in skeletal muscle tissue [11], where D-hormone participates in the regulation of calcium metabolism, and the control of muscular contraction and relaxation [6, 12-14]. It is hypothesized that the reduction in muscle strength and consequently higher susceptibility to falls with age may be partly explained by a reduction in the density or affinity of vitamin $\mathrm{D}$ receptors and/or D-hormone concentrations in the blood [15]. Although less used than cholecalciferol $\left(25-\mathrm{OH}-\mathrm{D}_{3}\right)$, the use of alfa $\mathrm{D}_{3}$ for the prevention of falls and fractures in elderly patients with primary osteoporosis is pathogenetically substantiated and evidence based (level I, meta-analyses) [16-20]. Alfa $\mathrm{D}_{3} 1 \mu \mathrm{g} /$ day was associated with a significant reduction in the number of falls $(-71 \%)$ among older patients with decreased creatinine clearance $(<65 \mathrm{~mL} / \mathrm{min})$ [10]. In a cohort study of 237 patients (mean age 75.9 years) administered alfa $D_{3} 1 \mu \mathrm{g} /$ day for 6 months, improvements in muscle strength and balance tests as well as an increase in the number of patients capable of performing them were demonstrated [21].

Current consensus is that $50 \mathrm{nmol} / \mathrm{L}(20 \mathrm{ng} / \mathrm{mL})$ should be the minimal serum $25-(\mathrm{OH}) \mathrm{D}$ concentration at the population level and in patients with osteoporosis to ensure optimal bone health. Below this threshold, supplementation is recommended at 800-1,000 IU/day (20-25 $\mu \mathrm{g} /$ day) [22]. Vitamin D production in the skin declines with advancing age, making elderly populations more dependent on dietary sources. Daily administration of oral vitamin $\mathrm{D}_{3}$ (600 IU) has been shown to achieve greater increases in serum $25(\mathrm{OH}) \mathrm{D}$ levels than weekly (4,200 IU) or monthly (18,000 IU) administration [23].

A number of pharmacological agents are available for the treatment of osteoporosis which act either to stimulate formation of new bone tissue or decrease bone resorption. Strontium ranelate (Les Laboratories Servier, France), registered as Bivalos in Uzbekistan, is the first agent of a new therapeutic class that has a dual mechanism of action, both promoting bone formation and inhibiting bone resorption. This rebalance of bone turnover leads to improvements in both trabecular and cortical bone microarchitecture and a shift towards formation of stronger bone [24, 25].

Although vitamin D supplementation is a fundamental part of osteoporosis treatment to improve bone microarchitecture and reduce risk of falls, many patients do not regularly take adequate amounts. In addition, active vitamin D metabolites have been found to be more effective for the prevention of falls among patients with osteoporosis than native vitamin D [12]. In this study, we evaluated the efficacy of strontium ranelate in combination with alfa $\mathrm{D}_{3}$ compared with strontium ranelate alone in postmenopausal women with osteoporosis in Uzbekistan.

\section{Methods}

The study recruited 48 women aged 54-73 years [mean age $62.4 \pm 1.46$ years, median 61.0 years; interquartile range (IQR) 58.0-64.3 years] with postmenopausal osteoporosis and a menopause duration of at least 1 year. Osteoporosis was diagnosed according to WHO criteria (1994) using $T$ score standard deviations (SDs) from the normative values of peak bone mass in healthy women. A value of not more than $-1 \mathrm{SD}$ was regarded as normal, a value of -1 to $-2.5 \mathrm{SD}$ as osteopenia, and $\leq-2.5 \mathrm{SD}$ as osteoporosis.

Women were randomized to strontium ranelate (SrRan) monotherapy $2 \mathrm{~g} /$ day $(n=16)$ or strontium ranelate $2 \mathrm{~g} /$ day plus alfa $\mathrm{D}_{3} 1 \mu \mathrm{g}(n=16)\left(\operatorname{SrRan}+\mathrm{AD}_{3}\right)$. The groups of patients were homogeneous, particularly for BMD. The sequence of drug course prescriptions for each patient was determined by the randomization method of "sealed envelopes." All patients were informed about the disease and its complications and gave informed consent to participate in the study.

All women received calcium supplements at a dose of $1,000 \mathrm{mg}$ and vitamin $\mathrm{D}_{3}$ at a dose of $800 \mathrm{IU} /$ day. $\mathrm{A}$ control group of 16 women received calcium $1,000 \mathrm{mg}$ and vitamin $\mathrm{D}_{3} 800 \mathrm{IU} /$ per day only. Physical load enhancement in the form of daily 30-min walking was recommended to all patients. Patients were recruited in one center and were followed up for 6 months on a monthly basis. Women with diseases affecting bone metabolism such as hyperparathyroidism, thyrotoxicosis, Itsenko-Cushing syndrome and disease, hypogonadism, malabsorption syndrome, kidney and liver disease, and malignancies were 
excluded, as were those taking medications that affect calcium metabolism in the 12 months prior to the study.

The primary objectives of the study were to assess the evolution of BMD and functional tests, to demonstrate that the combination treatment was superior to the other preparations in terms of efficacy. The secondary objective was to follow the evolution of biochemical markers of bone turnover.

To assess the efficacy of therapy, BMD was measured at the lumbar spine (L1-L4) and at the proximal femora at the beginning and end of therapy by dual energy $\mathrm{x}$-ray absorptiometry (DEXA), the gold standard for measurement of BMD, using a bone densitometer (Prodigy, CE Lunar Corporation, USA) in a private clinic "Doctor Summit" (Summit Trading Company, Ltd., Tashkent, Uzbekistan). In compliance with WHO criteria, BMD was expressed as $\mathrm{g} / \mathrm{cm}^{2}$ and $T$ score. Efficacy analyses were conducted according to the intention-to-treat (ITT) principle. The ITT population included all randomized patients who had taken at least one dose of treatment and who had a baseline and one post-baseline evaluation.

Patients were required to perform several functional tests to estimate risk of fall status. In the "up and go" test the patient was timed while rising from a chair with elbow rests, walking $3 \mathrm{~m}$, turning and bypassing an object on the floor before returning and sitting on the chair again. During the task the patient is permitted to use any accessory (e.g., a walking stick) that they use in everyday life [26]. Rising or sitting down safely as well as making a maneuver to bypass an object reveal a patient's ability to keep balance. The test therefore reflects actual, everyday abilities of the patient [27]. A previous study demonstrated that an increase in test time of $2.6 \mathrm{~s}$ was associated with a $24 \%$ increase in the risk of nonvertebral fracture [28].

In the chair rising test, the patient was observed and timed while rising from a standard chair five times with their arms folded, knees straightening with every rise. The test provides information about muscular power and operation speed of the lower extremities. A time of $10 \mathrm{~s}$ or less is evidence for good functional ability, while $11 \mathrm{~s}$ or more reflects poor functional ability [21, 29-31].

To assess the metabolic activity of bone remodeling, biochemical markers such as $\beta$-CrossLaps and type 1 procollagen total $\mathrm{N}$-terminal propeptide (TP1NP) were measured by means of electrochemiluminescence, Elecsys biochemical analyzer and Elecsys $\beta$-CrossLaps and TP1NP kits at baseline and after 6 months of therapy. An absorptiometric method was used to determine serum total calcium and nonorganic phosphorous, and a kinetic method was used to determine alkaline phosphatase activity by the amount of liberated 4-nitrophenol. Commercially available kits (CIS Bio International, France) were used to measure levels of parathyroid hormone (PTH).
All data were processed by Microsoft Excel, STATISTICA 6, and Biostat programs. Confidence of various quantitative parameters, including functional test data, was determined by Wilcoxon criteria; qualitative values were assessed by Irving Fisher criterion. Intergroup differences were considered significant at $P<0.05$.

The study was approved by the local ethics committee and conducted in accordance with the ethical principles stated in the Declaration of Helsinki of 1964 (revised in Seoul in 2008). Written informed consent was obtained from all patients participating in this study.

\section{Results}

The 48 patients were evaluated over 6 months on a monthly basis, and all patients completed the trial. The treatment groups were comparable in terms of medical history (Table 1). A high body mass index was noted in all groups, which is likely to be associated with the generally sedentary lifestyle and peculiarities of diet (pastries and foods roasted in animal fat) among postmenopausal women in Uzbekistan. Three women in the SrRan monotherapy group had experienced a previous fracture (wrist), as well as two women in the SrRan $+\mathrm{AD}_{3}$ group (one hip, one vertebral), and two women in the control group (one hip, one wrist). A family history of fractures was reported in four $(25.0 \%)$, three $(18.8 \%)$ and two $(12.5 \%)$ patients receiving SrRan, SrRan $+\mathrm{AD}_{3}$ and control, respectively. Menopause before the age of 45 years occurred in one $(6.3 \%)$, three $(18.8 \%)$ and one $(6.3 \%)$ women receiving SrRan, SrRan $+\mathrm{AD}_{3}$ and control, respectively.

Basal spine BMD was $0.745 \pm 0.01 \mathrm{~g} / \mathrm{cm}^{2}$ (median $0.742 \mathrm{~g} / \mathrm{cm}^{2}$; IQR 0.710-0.790); collum femoris BMD was $0.787 \pm 0.01 \mathrm{~g} / \mathrm{cm}^{2} \quad$ (median $\quad 0.779 \mathrm{~g} / \mathrm{cm}^{2} ; \quad \mathrm{IQR}$ 0.753-0.805).

\subsection{Bone Mineral Density}

Increases in BMD were observed at both the lumbar spine (L1-L4) and proximal femora in both strontium ranelate treatment groups (Table 2; Fig. 1). These increases were statistically significant compared with baseline values and compared with control. In the $\mathrm{SrRan}+\mathrm{AD}_{3}$ group, increases were also statistically significant compared with 6 months of treatment with SrRan monotherapy.

\subsection{Functional Ability Tests}

No significant changes in test times were observed in women in the control group or in those receiving SrRan only (Table 3). In contrast, the functional ability of women in the SrRan $+\mathrm{AD}_{3}$ group significantly increased. In this 
Table 1 Patient characteristics

\begin{tabular}{|c|c|c|c|}
\hline \multirow[t]{2}{*}{ Parameter } & \multicolumn{3}{|l|}{ Study treatment } \\
\hline & Control $(n=16)$ & $\operatorname{SrRan}(n=16)$ & $\operatorname{SrRan}+\mathrm{AD}_{3}(n=16)$ \\
\hline Age (years, mean \pm SD) & $62.9 \pm 1.52$ & $63.3 \pm 1.50$ & $61.1 \pm 1.35$ \\
\hline Median (IQR) & $62.5(58.8-65.3)$ & $62.5(59.8-65.8)$ & $59.5(58.8-62.0)$ \\
\hline $\mathrm{BMI}\left(\mathrm{kg} / \mathrm{m}^{2}\right.$, mean $\left.\pm \mathrm{SD}\right)$ & $31.2 \pm 1.14$ & $30.4 \pm 1.06$ & $32.7 \pm 0.50$ \\
\hline Median (IQR) & $30.0(28.5-33.4)$ & $29.2(28.1-32.4)$ & $32.0(30.8-34.5)$ \\
\hline Menopause age (years, mean \pm SD) & $50.5 \pm 0.89$ & $49.8 \pm 0.77$ & $46.8 \pm 1.36$ \\
\hline Median (IQR) & $50.0(47.8-53.0)$ & $50.0(47.8-50.8)$ & $45.5(44.3-50.8)$ \\
\hline Menopause duration (years, mean \pm SD) & $12.4 \pm 1.08$ & $13.5 \pm 1.23$ & $14.4 \pm 2.11$ \\
\hline Median (IQR) & $12.0(10.0-13.5)$ & $13.0(10.8-16.0)$ & $12.0(9.8-17.0)$ \\
\hline \multicolumn{4}{|l|}{ Fracture history $[n(\%)]$} \\
\hline Hip & $1(6.3)$ & $0(0)$ & $1(6.3)$ \\
\hline Wrist & $1(6.3)$ & $3(18.8)$ & $0(0)$ \\
\hline Spine & $0(0)$ & $0(0)$ & $1(6.3)$ \\
\hline Family history of fractures $[n(\%)]$ & $2(12.5)$ & $4(25.0)$ & $3(18.8)$ \\
\hline Menopause before 45 years $[n(\%)]$ & $1(6.3)$ & $1(6.3)$ & $3(18.8)$ \\
\hline
\end{tabular}

$A D_{3}$ alfacalcidol, $B M I$ body mass index, IQR interquartile range (25th-75th percentiles), $S D$ standard deviation, SrRan strontium ranelate

Table 2 Changes in BMD

\begin{tabular}{|c|c|c|c|c|c|c|}
\hline \multirow[t]{3}{*}{ Parameter } & \multicolumn{6}{|c|}{ Study treatment } \\
\hline & \multicolumn{2}{|c|}{ Control $(n=16)$} & \multicolumn{2}{|l|}{$\operatorname{SrRan}(n=16)$} & \multicolumn{2}{|c|}{$\operatorname{SrRan}+\mathrm{AD}_{3}(n=16)$} \\
\hline & Pre-therapy & Post-therapy & Pre-therapy & Post-therapy & Pre-therapy & Post-therapy \\
\hline \multicolumn{7}{|l|}{ Spine } \\
\hline $\mathrm{BMD}\left(\mathrm{g} / \mathrm{cm}^{2}\right.$, mean $\left.\pm \mathrm{SD}\right)$ & $0.741 \pm 0.02$ & $\begin{array}{l}0.742 \pm 0.01 \\
P=0.45\end{array}$ & $0.746 \pm 0.01$ & $\begin{array}{l}0.780 \pm 0.01 \\
P=0.04 \\
P_{\mathrm{c}}=0.03\end{array}$ & $0.749 \pm 0.01$ & $\begin{array}{l}0.810 \pm 0.01 \\
P<0.0001 \\
P_{\mathrm{c}}<0.001 \\
P_{\mathrm{SR}}=0.03\end{array}$ \\
\hline \% Change $(\downarrow \uparrow)($ mean \pm SD) & $\uparrow 0.24 \pm 0.45$ & & $\uparrow 4.65 \pm 0.56$ & & $\uparrow 8.18 \pm 0.62$ & \\
\hline Median (IQR) & $0.11(-1.43$ to & .40) & $4.78(2.59-5.67)$ & & $8.54(6.22-9.99)$ & \\
\hline \multicolumn{7}{|l|}{ Collum femoris } \\
\hline $\mathrm{BMD}\left(\mathrm{g} / \mathrm{cm}^{2}\right.$, mean $\left.\pm \mathrm{SD}\right)$ & $0.780 \pm 0.01$ & $\begin{array}{l}0.781 \pm 0.01 \\
P=0.41\end{array}$ & $0.780 \pm 0.003$ & $\begin{array}{l}0.805 \pm 0.01 \\
P<0.0001 \\
P_{\mathrm{c}}=0.02\end{array}$ & $0.799 \pm 0.02$ & $\begin{array}{l}0.862 \pm 0.02 \\
P=0.01 \\
P_{\mathrm{c}}=0.01 \\
P_{\mathrm{SR}}=0.01\end{array}$ \\
\hline \% Change $(\downarrow \uparrow)($ mean \pm SD) & $\uparrow 0.06 \pm 0.02$ & & $\uparrow 3.20 \pm 0.46$ & & $\uparrow 8.17 \pm 1.44$ & \\
\hline Median (IQR) & $0.12(0.0001-0$ & & $2.87(1.91-3.42)$ & & $6.10(4.97-9.38)$ & \\
\hline
\end{tabular}

$A D_{3}$ alfacalcidol, $B M D$ bone mineral density, $I Q R$ interquartile range (25th-75th percentiles), $P$ in relation to the parameter before therapy, $P_{c}$ in relation to the parameter in the control group, $P_{S R}$ in relation to the parameter in SrRan group after therapy, $S D$ standard deviation, $S r R a n$ strontium ranelate

group, times required to perform the "up and go" test and rising from a chair test were reduced and equilibrium test time increased both in relation to baseline values and posttherapy values in the control and SrRan groups. Thus, to perform the "up and go" test before therapy, patients required on average $15.88 \pm 0.95 \mathrm{~s}$ compared with $13.48 \pm 0.82 \mathrm{~s}$ after 6 months of therapy, a $14.26 \%$ reduction. In addition to improving patients' ability to perform functional tests, treatment with $\mathrm{SrRan}+\mathrm{AD}_{3}$ for 6 months also increased the number of women capable of performing the tests.

\subsection{Biochemical Markers of Bone Turnover}

Serum levels of $\beta$-CrossLaps were reduced compared with baseline in both strontium ranelate groups, by $18.7 \%$ with 
Fig. 1 Percentage increase in $\mathrm{BMD}$ at 6 months compared with baseline following treatment with control, strontium ranelate alone, or strontium ranelate in combination with alfacalcidol (DEXA results). $B M D$ bone mineral density, DEXA dual energy $\mathrm{x}$-ray absorptiometry

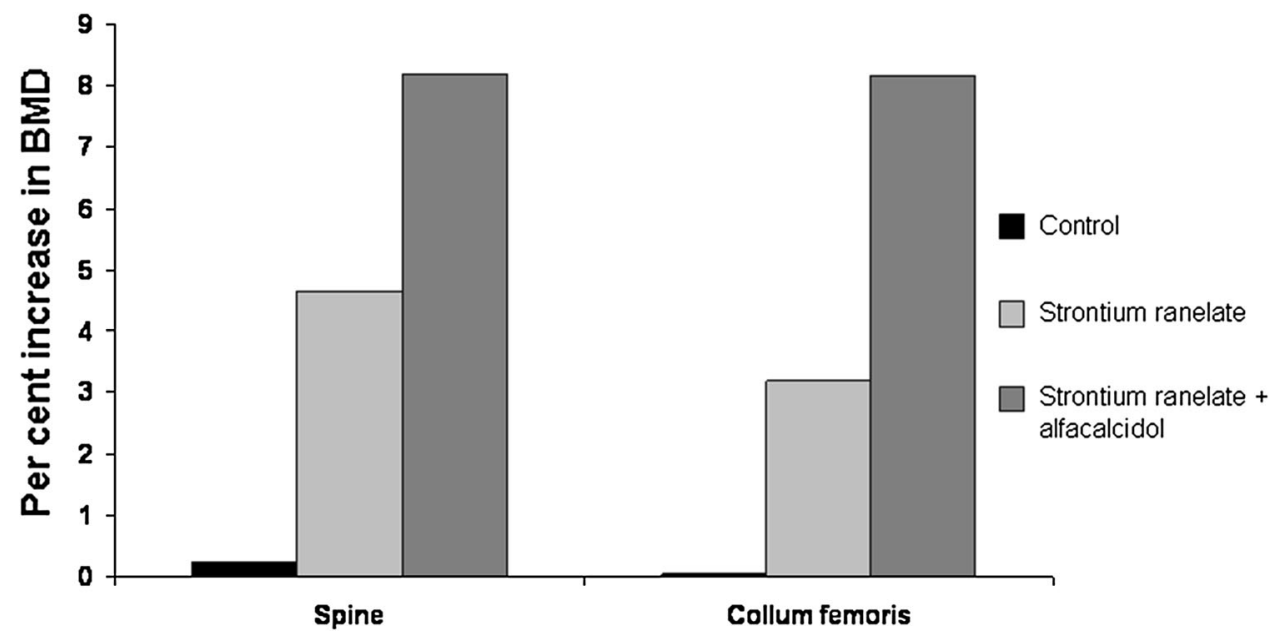

Table 3 Dynamics of functional parameters

\begin{tabular}{|c|c|c|c|c|c|c|}
\hline \multirow[t]{3}{*}{ Parameter } & \multicolumn{6}{|l|}{ Study treatment } \\
\hline & \multicolumn{2}{|l|}{ Control $(n=16)$} & \multicolumn{2}{|l|}{$\operatorname{SrRan}(n=16)$} & \multicolumn{2}{|c|}{$\operatorname{SrRan}+\mathrm{AD}_{3}(n=16)$} \\
\hline & Pre-therapy & Post-therapy & Pre-therapy & Post-therapy & Pre-therapy & Post-therapy \\
\hline $\begin{array}{l}\text { "Up and go" test } \\
(\mathrm{s}, \text { mean } \pm \mathrm{SD})\end{array}$ & $15.26 \pm 3.14$ & $\begin{array}{l}15.06 \pm 3.06 \\
P=0.37\end{array}$ & $15.74 \pm 3.45$ & $\begin{array}{l}15.69 \pm 3.41 \\
P=0.49 \\
P_{\mathrm{c}}=0.35\end{array}$ & $15.88 \pm 3.80$ & $\begin{array}{l}13.48 \pm 3.28 \\
P=0.01 \\
P_{\mathrm{c}}=0.07 \\
P_{\mathrm{SR}}=0.04\end{array}$ \\
\hline Median (IQR) & $16.0(12.0-17.8)$ & $16.0(12.0-17.2)$ & $16.0(13.2-18.3)$ & $15.2(13.0-18.4)$ & $17.2(11.5-18.4)$ & $13.2(11.0-15.6)$ \\
\hline $\begin{array}{l}\text { Difference vs. baseline } \\
\quad(\text { mean } \pm \text { SD) }\end{array}$ & & $0.20 \pm 0.08$ & & $0.05 \pm 0.18$ & & $2.40 \pm 0.53$ \\
\hline $\begin{array}{l}\% \text { Change }(\downarrow \uparrow) \\
(\text { mean } \pm \mathrm{SD})\end{array}$ & & $\downarrow 1.23 \pm 0.48$ & & $\downarrow 0.002 \pm 1.5$ & & $\downarrow 14.26 \pm 2.87$ \\
\hline $\begin{array}{l}\text { Rising from a chair test } \\
\quad(s, \text { mean } \pm S D)\end{array}$ & $16.85 \pm 2.31$ & $\begin{array}{l}16.81 \pm 2.36 \\
P=0.43\end{array}$ & $16.61 \pm 2.55$ & $\begin{array}{l}16.54 \pm 2.55 \\
P=0.48 \\
P_{\mathrm{c}}=0.42\end{array}$ & $16.83 \pm 3.12$ & $\begin{array}{l}13.86 \pm 2.53 \\
P=0.005 \\
P_{\mathrm{c}}=0.001 \\
P_{\mathrm{SR}}=0.006\end{array}$ \\
\hline Median (IQR) & $16.3(15.0-18.6)$ & $16.3(14.9-18.5)$ & $16.6(15.1-18.0)$ & $16.5(15.4-18.2)$ & $17.3(13.9-19.4)$ & $13.7(11.9-15.3)$ \\
\hline $\begin{array}{l}\text { Difference vs. baseline } \\
\quad(\text { mean } \pm \text { SD })\end{array}$ & & $0.04 \pm 0.02$ & & $0.07 \pm 0.10$ & & $2.97 \pm 0.57$ \\
\hline $\begin{array}{l}\text { \% Change }(\downarrow \uparrow) \\
(\text { mean } \pm \mathrm{SD})\end{array}$ & & $\downarrow 0.29 \pm 0.13$ & & $\downarrow 0.43 \pm 0.62$ & & $\downarrow 16.66 \pm 2.97$ \\
\hline $\begin{array}{l}\text { Equilibrium test } \\
(\mathrm{s}, \text { mean } \pm \mathrm{SD})\end{array}$ & $6.49 \pm 2.54$ & $\begin{array}{l}6.49 \pm 2.45 \\
P=0.46\end{array}$ & $6.68 \pm 2.95$ & $\begin{array}{l}6.69 \pm 2.88 \\
P=0.46 \\
P_{\mathrm{c}}=0.48\end{array}$ & $6.26 \pm 2.35$ & $\begin{array}{l}8.88 \pm 1.50 \\
P<0.001 \\
P_{\mathrm{c}}=0.003 \\
P_{\mathrm{SR}}=0.02\end{array}$ \\
\hline Median (IQR) & $5.63(4.79-8.44)$ & $5.66(4.51-8.51)$ & $6.41(4.07-9.42)$ & $6.47(4.22-9.21)$ & $6.04(4.8-7.5)$ & $10.0(7.0-10.0)$ \\
\hline $\begin{array}{l}\text { Difference vs. baseline } \\
\quad(\text { mean } \pm \text { SD) }\end{array}$ & & 0 & & $0.01 \pm 0.06$ & & $2.62 \pm 0.55$ \\
\hline $\begin{array}{l}\text { \% Change }(\downarrow \uparrow) \\
(\text { mean } \pm \mathrm{SD})\end{array}$ & & 0 & & $\uparrow 0.76 \pm 0.82$ & & $\uparrow 59.39 \pm 14.56$ \\
\hline
\end{tabular}

$A D_{3}$ alfacalcidol, IQR interquartile range (25th-75th percentiles), $P$ in relation to the parameter before therapy, $P_{c}$ in relation to the parameter in the control group, $P_{S R}$ in relation to the parameter in SR group after therapy, $S D$ standard deviation, SrRan strontium ranelate 
Table 4 Serum markers of bone turnover

\begin{tabular}{|c|c|c|c|c|c|c|}
\hline \multirow[t]{3}{*}{ Parameter } & \multicolumn{6}{|l|}{ Study treatment } \\
\hline & \multicolumn{2}{|l|}{ Control $(n=16)$} & \multicolumn{2}{|l|}{$\operatorname{SrRan}(n=16)$} & \multicolumn{2}{|c|}{$\mathrm{SrRan}+\mathrm{AD}_{3}(n=16)$} \\
\hline & Pre-therapy & Post-therapy & Pre-therapy & Post-therapy & Pre-therapy & Post-therapy \\
\hline $\begin{array}{l}\beta \text {-CrossLaps } \\
\quad(\mathrm{ng} / \mathrm{ml}, \\
\text { mean } \pm \mathrm{SD})\end{array}$ & $0.500 \pm 0.16$ & $\begin{array}{l}0.482 \pm 0.16 \\
P=0.30\end{array}$ & $0.481 \pm 0.16$ & $\begin{array}{l}0.384 \pm 0.11 \\
P=0.04 \\
P_{\mathrm{c}}=0.03\end{array}$ & $0.472 \pm 0.04$ & $\begin{array}{l}0.292 \pm 0.03 \\
P<0.0001 \\
P_{\mathrm{c}}<0.001 \\
P_{\mathrm{SR}}=0.008\end{array}$ \\
\hline $\begin{array}{l}\text { Median (IQR) } \\
\text { \% Change }(\downarrow \uparrow)\end{array}$ & $0.496(0.387-0.619)$ & $\begin{array}{l}0.470(0.369-0.598) \\
3.54 \downarrow\end{array}$ & $0.480(0.370-0.539)$ & $\begin{array}{l}0.421(0.294-0.432) \\
18.7 \downarrow\end{array}$ & $0.476(0.439-0.491)$ & $\begin{array}{l}0.302(0.261-0.314) \\
37.7 \downarrow\end{array}$ \\
\hline $\begin{array}{r}\text { TP1NP }(\mathrm{ng} / \mathrm{nl} \\
\text { mean } \pm \mathrm{SD})\end{array}$ & $0.294 \pm 0.06$ & $\begin{array}{l}0.304 \pm 0.11 \\
P=0.42\end{array}$ & $0.304 \pm 0.07$ & $\begin{array}{l}0.414 \pm 0.10 \\
P<0.0001 \\
P_{\mathrm{c}}=0.001\end{array}$ & $0.304 \pm 0.07$ & $\begin{array}{l}0.458 \pm 0.11 \\
P<0.0001 \\
P_{\mathrm{c}}<0.001 \\
P_{\mathrm{SR}}=0.10\end{array}$ \\
\hline Median (IQR) & $0.272(0.254-0.324)$ & $0.274(0.242-0.336)$ & $0.279(0.261-0.327)$ & $0.391(0.354-0.451)$ & $0.278(0.260-0.324)$ & $0.433(0.383-0.508)$ \\
\hline \% Change $(\downarrow \uparrow)$ & & $3.74 \uparrow$ & & $35.9 \uparrow$ & & $51.4 \uparrow$ \\
\hline $\begin{array}{l}\mathrm{PTH}(\mathrm{pg} / \mathrm{ml}, \\
\text { mean } \pm \mathrm{SD})\end{array}$ & $68.2 \pm 14.5$ & $\begin{array}{l}66.7 \pm 14.5 \\
P=0.16\end{array}$ & $69.4 \pm 7.69$ & $\begin{array}{l}65.4 \pm 8.35 \\
P=0.17\end{array}$ & $71.1 \pm 9.53$ & $\begin{array}{l}64.6 \pm 9.74 \\
P=0.03 \\
P_{\mathrm{c}}=0.28 \\
P_{\mathrm{SR}}=0.46\end{array}$ \\
\hline Median (IQR) & $66.7(62.7-80.7)$ & $64.9(60.2-79.7)$ & $68.6(63.4-72.9)$ & $65.1(59.4-69.2)$ & $71.7(63.4-75.6)$ & $62.9(60.2-67.9)$ \\
\hline \% Change $(\downarrow \uparrow)$ & & $2.26 \downarrow$ & & $5.84 \downarrow$ & & $9.29 \downarrow$ \\
\hline
\end{tabular}

$A D_{3}$ alfacalcidol, $I Q R$ interquartile range (25th-75th percentiles), $P$ compared with parameter before therapy, $P_{c}$ compared with parameter in the control group, $P_{S R}$ compared with parameter in SrRan group after therapy, $P T H$ parathyroid hormone, $S D$ standard deviation, SrRan strontium ranelate, $T P 1 N P$ type 1 procollagen total $\mathrm{N}$-terminal propeptide

SrRan and $37.7 \%$ with $\mathrm{SrRan}+\mathrm{AD}_{3}$ (Table 4). After 6 months of therapy, this marker of bone resorption was significantly reduced compared with control in patients receiving SrRan (20.3\%,P=0.03) and $\mathrm{SrRan}+\mathrm{AD}_{3}$ (39.4\%, $P<0.0001)$. A significantly greater reduction was also observed in the SrRan $+\mathrm{AD}_{3}$ group compared with SrRan only $(24.0 \% ; P=0.008)$.

Increases in TP1NP, a marker of bone formation, reached statistical significance in women receiving SrRan or a combination of SrRan $+\mathrm{AD}_{3}$ compared with baseline (35.9\%, $P<0.0001$, and $51.4 \%, P<0.001$, respectively). In the SrRan $+\mathrm{AD}_{3}$ group, the increase in TP1NP was also statistically significant compared with control (53.3 \%, $P<0.001)$. Reductions in mean PTH values were observed in the SrRan, SrRan $+\mathrm{AD}_{3}$ and control groups: $5.8,9.3$ and $2.3 \%$, respectively.

Laboratory investigations demonstrated normal parameters for calcium-phosphorus metabolism ( $\mathrm{Ca}, \mathrm{P}$ and alkaline phosphatase) in all groups, with no significant intergroup differences. Levels of calcium and phosphorus as well as alkaline phosphatase activity were in the reference limits, not changing significantly in any of the groups examined.

\subsection{Safety}

Two cases of dyspeptic events were reported (one patient in the SrRan group, one patient in the SrRan $+\mathrm{AD}_{3}$ group) and one case each of headache and arterial pressure rise (both in SrRan $+\mathrm{AD}_{3}$ group). All events were mild and reversible, and none resulted in withdrawal from the study.

\section{Discussion}

This study demonstrates that strontium ranelate in combination with alfa $\mathrm{D}_{3}$ is superior to strontium ranelate alone or a control treatment of calcium and vitamin D supplementation alone in improving BMD, functional ability, and biochemical markers of bone turnover in women with postmenopausal osteoporosis.

The superior efficacy of the combination treatment is likely to be a result of the complementary mechanisms of action of strontium ranelate and alfa $\mathrm{D}_{3}$. There is a substantial amount of evidence supporting the dual mode of action of strontium ranelate, with preclinical studies demonstrating stimulation of osteoblast proliferation and 
collagen synthesis in bone tissue culture, and reduced bone resorption as a result of suppression of osteoclast differentiation and activity [32-34].

An optimal therapy for osteoporosis would reduce fracture risk by increasing bone mass and strength as well as reducing falls. A number of authors have reported increases in lumbar and femoral BMD in postmenopausal women when treated with strontium ranelate. Povoroznyuk et al. [35] demonstrated increases in lumbar and femoral BMD in relation to baseline values of 1.5 and $5.6 \%$, respectively, at 3 months, and 3.4 and $6.1 \%$, respectively, at 6 months. Skripnikova et al. [25] reported significant increases in lumbar $(P<0.001)$ and proximal hip BMD $(P<0.01)$ after 6 months of therapy. After 12 months of therapy, increases in BMD in the above regions became even more pronounced compared with baseline: $6.6 \%$ lumbar spine $(P<0.001)$ and $3.2 \%$ proximal hip $(P<0.001)$, with BMD increase at the collum femoris also becoming statistically significant $(1.9 \%, \quad P<0.05)$. Compared with control, strontium ranelate increased BMD at the lumbar spine, proximal hip and collum femoris by $6.9,4.2$, and $2.5 \%$, respectively.

A Cochrane database review demonstrated that the minimum therapeutic dose of strontium ranelate $(1 \mathrm{~g} /$ day) significantly increased BMD at the collum femoris and lumbar spine by 4.78 and $5.53 \%$, respectively, within 2 years. Use of a $2 \mathrm{~g} /$ day dose facilitated an increase in lumbar BMD of $7.3 \%$ within 1 year of therapy and a $44 \%$ reduction in vertebral fractures within 2 years [36].

The findings from the 3-year study of strontium ranelate efficacy in Spinal Osteoporosis Therapeutic Intervention (SOTI) showed increases in lumbar, collum femoris and femur BMD of 12.7, 7.2 and 8.6\%, respectively [37]. In addition, treatment was associated with a reduction in the relative risk of new vertebral fractures of $49 \%$ at 1 year, $41 \%$ at 3 years and $33 \%$ at 4 years [37-39]. In the TReatment Of Peripheral OSteoporosis (TROPOS) trial, strontium ranelate $2 \mathrm{~g} / \mathrm{day}$ increased collum femoris and femur BMD by 5.7 and $7.1 \%$, respectively, over 3 years of treatment. There was a reduction in the relative risk of new vertebral fracture of $39 \%$ over 3 years, and $45 \%$ over the first year of treatment [40]. Further evidence that strontium-ranelate-induced increases in BMD translate into reduced fracture risk have been provided by an analysis of data from the SOTI and TROPOS trials [41, 42]. During 3 years of treatment with strontium ranelate, each percentage point increase in femoral neck and total proximal femur BMD was associated with a $3 \%$ (95\% adjusted confidence interval 1-5) and $2 \%(1-4)$ reduction in risk of new vertebral fracture, and explained three-quarters of the reduction in vertebral fractures observed during treatment. In a post hoc analysis of 465 women from the TROPOS trial aged $>74$ years with low femoral neck BMD, each
$1 \%$ increase in femoral neck BMD observed after 3 years was associated with a reduction in hip fracture incidence of $7 \%$.

It should be noted that in the SOTI and TROPOS pivotal trials with strontium ranelate, all patients were supplemented with $800 \mathrm{UI}$ of $25-\mathrm{OH}-\mathrm{D}_{3}$. In our study, BMD was measured after 6 months of treatment, with or without supplementation of alfa $\mathrm{D}_{3}$, so no comparison could be made with the 3-year results of from SOTI and TROPOS.

All osteoporotic patients treated with strontium ranelate must also be given vitamin $\mathrm{D}$, as vitamin D insufficiency is very frequent in these patients, and can be routinely and safely corrected [43]. A recent study has confirmed the efficacy and safety of an oral fixed-dose combination of strontium ranelate $2 \mathrm{~g} / \mathrm{vitamin} \mathrm{D} 1,000 \mathrm{IU}$ for correction of vitamin D insufficiency in osteoporotic patients [44].

The mainstay of current strategies to prevent osteoporotic fractures is to treat people with low BMD with antiosteoporotic drugs. However, it has been reported that the strongest single risk factor for fracture is falling and not osteoporosis [8,9]. Thus, preventing falls is a logical approach to preventing fracture. In addition to increasing bone density, vitamin $\mathrm{D}$ modulates fracture risk by improving muscle performance and decreasing falls. This has been demonstrated in a number of double-blind, randomized trials using doses of up to $1,000 \mathrm{IU}(25 \mu \mathrm{g})$ of vitamin D per day, with and without calcium. A metaanalysis of these trials showed that supplementation in amounts of $17.5-25 \mu \mathrm{g} /$ day (700-1,000 IU/day) lowered risk of falling by $20 \%$ in older individuals, independent of their level of calcium intake [45].

Functional tests to assess balance can give an indication of an individual's likelihood of suffering a fall [46]. Only the group receiving combination treatment with strontium ranelate and alfa $\mathrm{D}_{3}$ experienced improvements in functional ability, with time for the "up and go" and rising from a chair tests reduced by 14.3 and $16.7 \%$, respectively. Time for the equilibrium test increased by $59.4 \%$ compared with baseline. As all groups were receiving supplementary calcium and vitamin $\mathrm{D}$, the results suggest that it was the addition of alfa $\mathrm{D}_{3}$ that was improving functional ability. A previous study has shown that treatment with alfa $\mathrm{D}_{3}$ increases muscle power and balance and leads to a highly significant decrease in the number of fallers and falls [21]. More recently, a retrospective cohort analysis using patients from an osteoporosis database reported a statistically significant increase in muscle mass in alfa $\mathrm{D}_{3}$-treated patients with low muscle mass at baseline compared with a non-treated control group [47]. Other trials have also demonstrated that alfa $\mathrm{D}_{3}$ increases muscle power and balance and leads to a highly significant decrease in the number of fallers and falls [48]. 
The terminal stages of vitamin D metabolism in the kidney are regulated by feedback mechanisms, and vitamin $\mathrm{D}$ in the form of a food supplement has no effect on levels of D-hormone formation. We believe that in the absence of vitamin $\mathrm{D}$ deficiency, the pharmacological effects of D-hormone ana$\operatorname{logs}$, such as alfa $\mathrm{D}_{3}$, on bones, muscles and other target organs are likely to be greater than vitamin D [49, 50]. Meta-analyses of randomized clinical studies that compared the efficacy of active vitamin $D$ metabolites with native vitamin $D$ in relation to fracture risk and falls found that fracture risk reduction was not dependent on BMD parameters before treatment or calcium supplementation [17, 20, 51].

Two opposed processes, bone formation and bone resorption, characterize bone metabolism. Type 1 collagen degradation product, type $1 \mathrm{C}$-telopeptide ( $\beta$-CrossLaps), is a parameter characterizing the degree of bone tissue resorption, while TP1NP is a marker of bone matrix formation. Increases in $\beta$-CrossLaps are believed to be the primary and most sensitive parameter of the shift in balance from bone remodeling towards bone resorption [52]. In this study, both strontium ranelate groups significantly decreased serum levels of $\beta$-CrossLaps compared with baseline, with the greatest reductions achieved in the combined treatment group. Strontium ranelate was also associated with significant increases in TP1NP levels, with the most benefit again observed in the combined treatment group.

Parathyroid hormone is a key regulator of calciumphosphorus metabolism. It is synthesized by the parathyroid glands in response to a reduction in extracellular calcium concentrations, and activates osteoclasts to increase bone resorption (demineralization, bone destruction) and therefore calcium and phosphorus release into the circulation. Increases in PTH levels, particularly in elderly individuals with vitamin $\mathrm{D}_{3}$ deficiency, can result in osteomalacia, increased bone remodeling, bone mass reduction and fractures [53]. Reductions in PTH levels were observed in all treatment groups, but only achieved statistical significance in the combined strontium ranelate and alfa $\mathrm{D}_{3}$ treatment group.

This study has a number of limitations, including an open-label design and small sample size. A longer-term, large, randomized, double-blind study is now required to determine whether the benefits of strontium ranelate and alfa $\mathrm{D}_{3}$ will lead to a reduction in the risk of falls and fractures.

\section{Conclusion}

Combined therapy with the established antiosteoporosis treatment strontium ranelate and the D-hormone analog alfa $\mathrm{D}_{3}$ increased the benefits observed with strontium ranelate alone in terms of improved bone quality, enhanced muscular power and neuromuscular coordination, and improved levels of markers of bone turnover.

Acknowledgments The interpretation and conclusions contained in this report are those of the authors alone. This study was funded by representatives of Servier company in Uzbekistan, which was not involved in designing and conducting the study, nor in the collection, analysis and interpretation of the data.

Conflict of interest The authors declare that there are no conflicts of interest regarding the publication of this paper.

Open Access This article is distributed under the terms of the Creative Commons Attribution Noncommercial License which permits any noncommercial use, distribution, and reproduction in any medium, provided the original author(s) and the source are credited.

\section{References}

1. Toroptsova NV, Nikitinskaya OA, Demin NV, Benevolenskaya LI. Prevention of post-menopausal osteoporosis, results of threeyear observation (in Russian). Sci Pract Rheumatol. 2006;5:25-32.

2. Barrett-Connor E. Osteoporosis and fracture risk in women of different ethnic groups. J Bone Miner Res. 2005;33:19-24.

3. Cauley J. Prevalent vertebral fractures in black women and white women. J Bone Miner Res. 2008;23(9):1458-67.

4. Lansdown D, Bennet B, Thiel S, Ahmed O, Dixon L, Vokes T. Prevalence of vertebral fractures on chest radiographs of elderly African American and Caucasian women. Osteoporos Int. 2011;22(8):2365-71.

5. Kandiloytu AYu. Osteopenic syndrome in per-menopausal female residents of Tashkent, its correction. Author's abstract for Candidate of Science Thesis (in Russian). Tashkent; 2005. p. 24.

6. Ershova OB, Belova KYu, Ganert OA, Nazarova AV, Romanova MA, Sinitsyna OS. Arrangement of care for osteoporotic patients with proximal hip fractures (in Russian). Russ Med J. 2010;27:38-42.

7. Jarvinen T, Sievanen H, Khan K, Heinonen A, Kannus P. Shifting the focus in fracture prevention from osteoporosis to falls. $\mathrm{Br}$ Med J. 2008;336:124-6.

8. Kannus P. Why is the age-standardized incidence of low-trauma fractures rising in many elderly populations? J Bone Miner Res. 2002;17:1363-7.

9. Kannus P, Sievanen H, Palvanen M, Jarvinen T, Parkkari J. Prevention of falls and consequent injuries in elderly people. Lancet. 2005;366:1885-93.

10. Dukas L, Schacht E, Mazor Z, Stahelin H. Treatment with alfacalcidol in elderly people significantly decreases the high risk of falls associated with a low creatinine clearance of $<65 \mathrm{ml} / \mathrm{min}$. Osteoporos Int. 2005;16:198-203.

11. Bischoff H, Borchers M, Gudat F, et al. In situ detection of 1.25dihydroxyvitamin $\mathrm{D}$ receptor in human skeletal muscle tissue. Histochem J. 2001;33:19-24.

12. Belaya JE, Rojinskaya LYa. Falls as a significant social problem among elders. Basic mechanisms of its onset and progression and ways for prevention (in Russian). Russ Med J. 2009;24:28-34.

13. Maki B, Mcllroy W. Control of rapid limb movements for balance recovery: age-related changed and implications for fall prevention. Age Ageing. 2006;35(Suppl 2):12-8.

14. Boland R. Role of vitamin D in skeletal muscle function. Endocr Rev. 1986;784:434-48. 
15. Schacht E, Richy F, Reginster J-Y. The therapeutic effects of alfacalcidol on bone strength, muscle metabolism and prevention of falls and fractures. $\mathbf{J}$ Musculoskelet Neuronal Interact. 2005;5(3):273-84.

16. De Nijs R, Jackbs J, Algra A. Prevention and treatment of glucocorticoid-induced osteoporosis with active vitamin $\mathrm{D}_{3}$ analogues: a review with meta-analysis of randomized controlled trails including organ transplantation studies. Osteoporos Int. 2004;15(8):589-602.

17. Dukas L, Bischoff HA, Lindpaintner LS, et al. Alfacalcidol reduces the number of fallers in a community-dwelling elderly population with a minimum calcium intake of more than $500 \mathrm{mg}$ daily. J Am Geriatr Soc. 2004;52:230-6.

18. Dukas L, Schacht E, Bischoff H. Better functional mobility in community dwelling elderly is related to D hormone serum levels and to daily calcium intake. J Nutr Health Aging. 2005;9(5):347-51.

19. Richy F, Ethgen O, Bruyere O. Vitamin D analogs versus native vitamin $\mathrm{D}$ in preventing bone loss and osteoporosis-related fractures: a comparative meta-analysis. Calcif Tissue Int. 2005;76:176-86.

20. Richy F, Dukas L, Schacht E. Differential effects of D hormone analogs and native vitamin D on the risk of falls: a comparative meta-analysis. Calcif Tissue Int. 2008;82(2):102-7.

21. Dukas L, Schacht E, Runge M, Ringe J. Effect of a six-month therapy with alfacalcidol on muscle power and balance and the number of fallers and falls. Arzneimittelforschung. 2010;60:519-25.

22. Rizzoli R, Boonen S, Brandi ML, et al. Vitamin D supplementation in elderly or postmenopausal women: a 2013 update of the 2008 recommendations from the European Society for Clinical and Economic Aspects of Osteoporosis and Osteoarthritis (ESCEO). Curr Med Res Opin. 2013;29(4):305-13.

23. Chel V, Wijnhoven H, Smit J, Ooms M, Lips P. Efficacy of different doses and time intervals of oral vitamin D supplementation with or without calcium in elderly nursing home residents. Osteoporos Int. 2008;19(5):663-71.

24. Rojinskaya LYa, Belyaeva AV, Belaya JE. Strontium ranelate (Bivalos) - a medication with two-sided effect on bone tissue; novel approaches to treatment of osteoporosis. Osteoporos Osteopenia. 2006;1:34-43.

25. Skripnikova IA, Poddubskaya EA, Kosmatova OV, et al. Usage of Bivalos (strontium ranelate) in post-menopausal osteoporosis (in Russian). Sci Pract Rheumatol. 2009;2:43-8.

26. Podsialdo D, Richardson S. The timed "up and go": a test of basic functional mobility for frail elderly persons. J Am Geriatr Soc. 1991;39(2):142-8.

27. Mathias S, Nayak U, Isaacs B. Balance in elderly patients: the "get-up and go" test. Arch Phys Med Rehabil. 1986;67:387-9.

28. Zhu K, Devine A, Lewis JR, Dhaliwal SS, Prince RL. Timed 'up and go' test and bone mineral density measurements for fracture prevention. Arch Intern Med. 2011;171:1655-61.

29. Gill T, Williams C, Tinetti M. Assessing risk for the onset of functional dependence among older adults: the role of physical performance. J Am Geriatr Soc. 1995;43:603-9.

30. Runge M, Rehfeld G, Resnicek E. Balance training and exercise in geriatric patients. J Musculoskelet Neuronal Interact. 2000;1:54-8.

31. Verhaar H, Samson M, Jansen P, et al. Muscle strength, functional mobility and vitamin D in older women. Aging Clin Exp Res. 2000;12:268-74.

32. Ammann P. Strontium ranelate: a novel mode of action leading to renewed bone quality. Osteoporos Int. 2005;16:11-6.

33. Blake G, Foglman I. Long-term effect of strontium ranelate on BMD. J Bone Miner Res. 2005;20:190-4.

34. Buehler J, Chappuis P, Saffar J. Strontium ranelate inhibits bone resorption while maintaining bone formation in alveolar bone in moneys (Macaca fascicularis). Bone. 2001;29:176-9.
35. Povoroznyuk VV, Dzerovich NI, Orlik TV, Vaida VM. Effect of strontium ranelate on bone mineral density and vertebral pain syndrome in post-menopausal women: literature data and the authors' studies. Probl Osteol (Ukraine). 2008;11(1-2):15-24.

36. O'Donnel S, Cranney A, Wells GA, Adachi JD, Reginster JY. Strontium ranelate for preventing and treating postmenopausal osteoporosis. Cochrane Database Syst Rev. 2006;3:CD005326.

37. Meunier P, Roux C, Seeman E, et al. The effects of strontium ranelate on the risk of vertebral fracture in women with postmenopausal osteoporosis. N Engl J Med. 2004;350:459-68.

38. Reginster J, Deroisy R, Dougados M, et al. Prevention of early postmenopausal bone loss by strontium ranelate: the randomized, two-year, double-masked, dose-ranging, placebo-controlled (PREVOS) trial. Osteoporos Int. 2002;13:925-31.

39. Seeman E, Vellas B, Benhamou C, et al. Strontium ranelate reduces the risk of vertebral and nonvertebral fractures in women eighty years of age and older. J Bone Miner Res. 2006;21: 1113-20.

40. Reginster J, Seeman E, De Vernejoul M, et al. Strontium ranelate reduces the risk of nonvertebral fractures in postmenopausal women with osteoporosis: Treatment of Peripheral Osteoporosis (TROPOS) study. J Clin Endocrinol Metab. 2005;90:2816-22.

41. Bruyere O, Roux C, Badurski J, Isaia G, De Vernejoul MC, Cannata J, et al. Relationship between change in femoral neck bone mineral density and hip fracture incidence during treatment with strontium ranelate. Curr Med Res Opin. 2007;23:3041-5.

42. Bruyere O, Roux C, Detilleux J, Slosman DO, Spector TD, Fardellone P, et al. Relationship between bone mineral density changes and fracture risk reduction in patients treated with strontium ranelate. J Clin Endocrinol Metab. 2007;92:3076-81.

43. Rizzoli R, Dawson-Huges B, Kaufman J-M, et al. Correction of vitamin $\mathrm{D}$ insufficiency with combined strontium ranelate and vitamin D3 in osteoporotic patients. Eur $\mathrm{J}$ Endocrinol. 2014;170:441-50.

44. Rizzoli R, Dawson-Hughes B, Kaufman JM, Fardellone P, Brandi ML, Vellas B, Collette J, Reginster JY. Correction of vitamin D insufficiency with combined strontium ranelate and vitamin D3 in osteoporotic patients. Eur J Endocrinol. 2014;170:441-50.

45. Bischoff-Ferrari H, Willett W, Wong J, et al. Prevention of nonvertebral fractures with oral vitamin D and dose dependency: a meta-analysis of randomized controlled trials. Arch Intern Med. 2009;169(6):551-61.

46. Guralnik J, Ferrucci L, Simonsick E, Salive M, Wallace R. Lower-extremity function in persons over the age of 70 years as a predictor of subsequent disability. N Engl J Med. 1995;332: 556-61.

47. Ito S, Harada A, Kasai T, Sakai Y, Takemura M, Matsui Y, Hida $\mathrm{T}$, Ishiguro $\mathrm{N}$. Use of alfacalcidol in osteoporotic patients with low muscle mass might increase muscle mass: an investigation using a patient database. Geriatr Gerontol Int. 2014;14(Suppl 1):122-8

48. Dukas L, Schacht E, Runge M, Ringe JD. Effect of a six-month therapy with alfacalcidol on muscle power and balance and the number of fallers and falls. Arzneimittelforschung. 2010;60: $519-25$.

49. Nordin B, Need A, Morris H, Horowitz M. The special role of "hormonal" forms of vitamin D in the treatment of osteoporosis. Calcif Tissue Int. 1999;65:307-10.

50. Lau K, Baylink D. Vitamin D therapy of osteoporosis: plain vitamin $\mathrm{D}$ therapy versus active vitamin $\mathrm{D}$ analog (D hormone) therapy. Calcif Tissue Int. 1999;65:295-306.

51. Richy F, Ethgen O, Bruyere O. Efficacy of alphacalcidol and calcitriol in primary and corticosteroid-induced osteoporosis: a meta-analysis of their effects on bone mineral density and fracture rate. Osteoporos Int. 2004;15(4):301-10. 
52. Delmas P, Eastell R, Garnero P, Committee of Scientific Advisors of the International Osteoporosis Foundation. The use of biochemical markers of bone turnover in osteoporosis. Osteoporos Int. 2000;6:2-17.
53. Kostyuchek DF, Dushenkova TA, Rischuk SV. Early diagnosis of osteoporosis in pre- and post-menopausal women (in Russian). J Obstet Women Dis. 2006;55(1):3-7. 